Ks. Stanislaw Mędala

\title{
SPRAWOZDANIE Z DZIALALNOŚCI POLSKIEGO TOWARZYSTWA TEOLOGICZNEGO W KRAKOWIE W ROKU 1977
}

\begin{abstract}
W roku sprawozdawczym Polskim Towarzystwem Teologicznym w Krakowie kierował zarząd wybrany na Walnym Zebraniu $w$ dniu 28 stycznia 1977 r. w składzie: ks. prof. dr hab. Bolesław Przybyszewski (prezes), ks. prof. dr hab. Tadeusz Wojciechowski (wiceprezes), ks. dr Stanisław M ędala CM (sekretarz), ks. lic. Mieczysław Piłat SDB (skarbnik) i ks. dr hab. Antoni Baciński CM (bibiotekarz). Skład Komisji Rewizyjnej był następujący: przewodniczacy ks. dr Stanisław Dabrows ki i członkowie: ks. dr Franciszek M a charski i ks. dr Miłosław Kołodzi ejczyk. Praca Towarzystwa odbywała się zgodnie ze Statutem, obejmując akcją odczytową na zebraniach zwyczajnych i sekcyjnych oraz działalność wydawniczą.
\end{abstract}

W okresie sprawozdawczym odbyło się osiem zebrań zwyczajnych, w których oprócz członków zwyczajnych i wspierających brali udział księża zainteresowani poruszaną problematyką. O zebraniach zwyczajnych informowano czlonków i zainteresowanych gości poprzez komunikaty rozsyłane przez Wydzial Duszpasterski Kurii Metropolitalnej w Krakowie. Tematyka odczytowa zebrań zwyczajnych dotyczyæa aktualnych wydarzeń w życiu Kościoła, ważniejszych rocznic i zagadnień teologicznych związanych $z$ duszpasterstwem.

Ks. rektor dr Franciszek $\mathrm{M}$ a charski w referacie pt. Odpowiedzialność parafii za duszpasterstwo parafialne podzielił się swoimi refleksjami $\mathrm{z}$ narady duszpasterskiej w Wiedniu w dniach 27-30 XII $1976 \mathrm{r}$. na temat „Parafia żywa” (19 III 1977). Ks. dr Marian Jakubie c omówił problematykę IV Synodu Biskupów odbytego w Rzymie w dniach 30 IX -29 X 1977 r. (15 XII 1977). W związku z 750 rocznicą śmierci św. Franciszka z Asy$\dot{z} u$, o. dr Cecylian $\mathrm{Niezg}$ oda OFMConv. wygłosił referat pt. Aktualność idei franciszkańskiej (17 II 1977). Do aktualnych zagadnień w życiu Kościoła należy sprawa synodu prowincji krakowskiej, którego teologię w świetle struktur Kościoła starożytnego przedstawił ks. dr Kazimierz $\mathrm{Kupiec} \mathrm{z}$ Tarnowa $\mathrm{w}$ referacie pt. Elementy metropolii $i$ synodu prowincjonalnego $w$ świetle struktur Kościoła starożytnego (20 X 1977). Prof. Marian Plezia miał odczyt nt. W 500 rocznice śmierci Grzegorza z Sanoka, arcybiskupa lwowskiego (17 XI 1977). Z okazji 50-lecia istnienia Niepokalanowa o. dr Cecylian $\mathrm{Niezgoda}$ OFMConv. wygłosił referat pt. Powstanie i charakter Niepokalanowa jako dzieła błog. Maksymiliana Marii Kolbego (19 V 1977). Ks. mgr Wojciech Bołoz CSSR z Tuchowa wystąpił z referatem pt. Rola niedzieli $w$ życiu chrześcijanina (15 IX 1977). Ostatnie zebranie (19 I 1978) poświęcono ks. Józefowi Winkowskiemu; dr Zofia Roszek mówiła O działalności ks. Józefa Winkowskiego a dr Maria Kwarcińska nt. Ks. J. Winkowski jako wychowawca.

\section{II}

Ożywioną działalność prowadziły poszczególne sekcje, na których wygłoszono lącznie 58 referatów poruszających problematykę z zakresu ich specjalności. Dwie sekcje prowadziły prace zespołowe: sekcja filozoficzna na temat śmierci ludzkiej, a sekcja biblijno-liturgiczna opracowywała dzieło „Vademecum biblijne”. 
Sekcja filozoficzna, którą kierował ks. prof. dr hab. Tadeusz W ojciechowski, odbyła cztery zebrania. Omówiono na nich tematy dotyczące interdyscyplinarnie ujętego zagadnienia śmierci ludzkiej. Referaty wygłosili: ks. doc. dr hab. Józef $\mathrm{T}$ is chner, Fenomenologia śmierci (22 III 1977), prof. dr Julian Blicharski, Smierć w ujęciu medycyny (17 V 1977), ks. dr Henryk Piszkalski, Psychologia śmierci (15 XI 1977) i ks. dr Stanisław Pis a rek, Życie i śmierć w Piśmie św. (13 XII 1977). Zebrania odbywały się w sali Wyższego Seminarium Duchownego w Krakowie przy ul. Manifestu Lipcowego 4. Liczba uczestniczących w zebraniach była stosunkowo duża, gdyż w pierwszym zebraniu wzięło udział. 40 osób, w drugim 21 osób, w trzecim 42 osoby i w czwartym 16 osób.

Sekcja biblijno-liturgiczna, prowadzona przez ks. doc. dra hab. Jerzego $\mathrm{Chmiela,} \mathrm{odbyła} \mathrm{cztery} \mathrm{posiedzenia} \mathrm{z}$ referatami i dyskusją. Referaty wygłosili: ks. dr Władysław Borowski CRL, Rib-Pattern $w$ Pwt 32 (16 III 1977), ks. doc. dr hab. Jerzy Chmiel, Nauczanie Pisma św. $w$ świetle dokumentu Kongregacji o formacji teologicznej przyszłych kapłanów (15 VI 1977), ks. dr Antoni Dreja, Rola podręcznika biblijnego $w$ nauczaniu seminaryjnym ( 7 XII 1977). Jedno spotkanie (26 X 1977) poświęcono pamięci zmarłego o. Ludwika Se mk owskiego T'J, którego działalność naukową i dydaktyczną przedstawił ks. doc. dr hab. Jerzy Chmiel. Oprócz zebrań dyskusyjnych z referatami sekcja biblijno-liturgiczna prowadziła zespół redakcyjny, mający na celu opracowanie dzieła pt. Vademecum biblijne. Zebrania tego zespołu odbywały sie po zebraniach dyskusyjnych nad referatami przedstawionymi jej przez prelegentów. Miejscem spotkań była aula Wyższego Seminarium Duchownego w Krakowie przy ul. Podzamcze 8.

Sekcja apologetyczno-religioznawcza, której kierownikiem jest ks. infułat prof. dr hab. Eugeniusz Florkowski, odbyła cztery zebrania z następującymi referatami: o. prof. dr hab. Augustyn J a n kowski OSB, Transcendencja Chrystusa jako Syna Bożego (26 I 1977), ks. dr Adam Kubiś, Wybrane problemy kolegializmu we wspótczesnym wykładzie apologetycznym (18 III 1977), ks. dr Michał K a s z wski, System eklezjologii eucharystycznej M. Afanasjewa (26 IV 1977), ks. prof. dr Stanisław $\mathrm{Nagy}$ SCJ, Przynależność do Kościoła według Soboru Watykańskiego II $i$ wspótezesnej teologii (16 XII 1977). Zebrania odbywały się w auli Wyższego Seminarium Duchownego w Krakowie przy ul. Podzamcze 8.

Sekcja dogmatyczno-moralna, na czele której stał o. dr Jan W i chrow ic z OP, odbyła sześć zebrań. Referaty wygłosili: ks. dr Engelbert Goryw oda SDB, Grzech pierworodny w interpretacji Pieta Schoonenberga (9 II 1977), ks. dr Jan Hojnowski SCJ, Gtówne elementy metody teologicznej wedlug Vaticanum II (2 III 1977), o. dr Bogdan Brzuszek OFM, Sakrament bierzmowania jako podstawa apostolstwa (3 X 1977), o. dr Jan W i chrowicz OP, Samuel Wierzchoński OP teolog moralista $z$ pierwszej połowy XVII wieku (3 X 1977), o. dr Salezy Kafel OFMCap, Miłość wspólnoty małżenskiej według „Gaudium et spes" (7 XI 1977), o. dr Otto Filek OCD, 400 lat „Twierdzy wewnętrznej" sw. Teresy $z$ Avila (5 XII 1977). Posiedzenia sekcji miały miejsce w auli Instytutu Filozoficzno-Teologicznego OO. Dominikanów przy ul. Stolarskiej 12 .

Sekcja historyczno-kanoniczna, pod kierunkiem ks. dra Kazimierza Drzymały TJ, odbyła sześć zebrań, na których omówiono następujące tematy: Ks. Marcin Smiglecki TJ, największy ekonomista, teolog, polemista $i$ filozof na przełomie XVI $i$ XVII w. (ks. dr Kazimierz Drzymała TJ - 19 I 1977), Geneza powstania ruskiej prowincji dominikańskiej (o. Robert S więtochow ski OP - 16 II 1977), Kolegium jezuickie $w$ Krakowie przy ul. Kopernika (ks. dr Jerzy Kontkowski 
TJ - 20 IV 1977), Kraków i diecezja krakowska za ks. Jacka Łopackiego (ks. dr hab. Jan Kuś - 19 X 1977), Działalność misyjna polskich franciszkanów w Danii (o. dr Damian S y now i e c OFMConv. - 11 XI 1977), Ks. Józef Winkowski - diugoletni katecheta w Zakopanem (dr Zofia R oszek - 14 XII 1977). Gościny dla zebrań tej sekcji udzielało głównie Wyższe Seminarium Duchowne przy ul. Podzamcze 8.

Sekcja mis jologi czna, którą prowadzi ks. dr hab. Antoni B ac iński CM, odbyła pięć zebrań z referatami: ks. wizytator dr Tadeusz Gocławski CM, Moje wrażenia $z$ wizytacji polskiej misji na Maciagaskarze (23 II 1977), ks. Jerzy Morkis CM, Misjonarska dzialalność wśród Polonii brazylijskiej (27 IV 1977), ks. dr Ludwik Grze bień TJ, Misje katolickie $w$ Zambii (1 VI 1977), ks. superior Ryszard Falkiewi c z SDS, Udział Księży Salwatorianów w misjach zagranicznych (25 X 1977), ks. Tomasz Bulc CSSR, Misja Ojców Redemptorystów w Brazylii (29 XI 1977). Referaty, ilustrowane przeźroczami, przyciągały znaczną ilość słuchaczy. Zebrania odbywały się w auli Wyższego Seminarium Duchownego w Krakowie przy ul. Podzamcze 8.

Sekcja pastoralno-homiletyczna w Kalwarii Zebrzydowskiej, pod kierownictwem o. dra Czesława Teklaka OFMBern., odbyła pięć zebrań z referatami i dyskusją: o. doc. dr hab. Feliks $\mathrm{Z}$ a płata SDV, Wkład misji katolickich $w$ dzieło wyzwolenia Afryki dawniej $i$ dzisiaj (13 I 1977), o. dr Florentyn Piwosz OFMBern., $Z$ problematyki socjologii parafii (8 III 1977), o. mgr Kazimierz Z u chow sk i OFMBern., Łacińscy poeci bernardyńscy $w$ XVI $i$ XVII wieku (11 V 1977), o. mgr Bogumił Migdał OFMBern., Misje ludowe bernardynów $w$ prowincji galicyjskiej $i w$ wolnej Polsce (15 XI 1977), o. dr Feliks Marchewka OFMBern., Główne zagadnienia metaetyki (9 XII 1977). W pracach sekcji homiletyczno-duszpasterskiej PTT brali udział profesorzy i studenci Wyższego Seminarium Duchownego OO. Bernardynów w Kalwarii Zebrzydowskiej i w Krakowie, jak również księża dekanatu kalwaryjskiego i okolic Kalwarii oraz ojcowie z klasztorów bernardyńskich w Krakowie, Alwernii, Tarnowie i Zakopanem.

Sekcja PTT w Tarnowie, kierowana przez ks. doc. dra hab. Leopolda $\mathrm{R}$ egnera, odbyła pięć zebrań z następującymi referatami: ks. dr Michał Bednarz, Teologia biblijna $i$ jej metoda (11 I 1977), ks. dr hab. Jan Dudziak, Dażenie oiskupów do decentralizacji władzy dysponowania $w$ prawie małzeńskim na Soborze Watykańskim I (22 II 1977), ks. dr Kazimierz Kupiec, Elementy teologii metropolii i synodu prowincjonalnego $w$ świetle struktur Kościola starożytnego (26 IV 1977), ks. lic. Kazimierz Macheta, Rozumienie katolickiej teologii historii (17 V 1977), ks. dr hab. Jan Dudziak, Przeobrażenia w zakresie kościelnej normy prawnej (29 XI 1977).

Sekcja P T T w Tuchowie, prowadzona przez ks. mgra Andrzeja $\mathrm{R}$ ę ba c z a CSSR, urządzila osiem posiedzeń, na których wygłoszono następujące referaty: s. doc. dr hab. Zofia $\mathrm{Zd} \mathrm{y} \mathrm{bicka,} \mathrm{Typologia}$ koncepcji filozofii religii (5. III 1977), s. doc. dr hab. Zofia Z dy bicka, Koncepcja religii $w$ filozofii religii wedlug św. Tomasza (6 III 1977), ks. bp dr Stanisław Smoleński, Etyczny wymiar rodzicielskiego obowiazku przekazywania życia (21 IV 1977), o. mgr Wojciech Bołoz CSSR, Rola seminarium naukowego $w$ ksztaltowaniu seminaryjnym (10 V 1977), o. mgr Andrzej $\mathrm{Rębacz} \mathrm{CSSR,} \mathrm{Sprawozdanie} \mathrm{z} \mathrm{sympozjum} \mathrm{sekcji} \mathrm{profesorów}$ filozofii wyższych uczelni $w$ Polsce $w$ dniach 20 i 21 września 1977 r. na ATK $w$ Warszawie (11 $\mathrm{x}$ 1977), o. dr Emil $\mathrm{S}$ tanula CSSR, Alegoria a typologia w patrystyce (20 X 1977), o. mgr Gerard S i w ek, Retorykawróg czy sprzymierzeniec? (8 XI 1977), o. mgr Mieczysław W it a li s CSRR, Teologia św. Alfonsa na Międzynarodowym Sympozjum Alfonsjańskim $w$ Rzymie - Alfonsianum 1-27 X 1977 (13 XII 1977). W zebraniach sek- 
cji PTT w Tuchowie brali udział Ojcowie Redemptoryści z Tuchowa i Krakowa oraz klerycy Wyższego Seminarium Duchownego w Tuchowie.

Sekcja dia studium problemów Soboru Watykańskiego II, której patronował ks. prof. dr hab. Bolesław Przybyszewski, a w zastępstwie kierownika prowadził ją ks. mgr Stanisław Swięcicki, miała posiedzenia raz $w$ miesiącu $w$ pomieszczeniach klasztornych SS. Wizytek przy ul. Krowoderskiej 17.

III

Sekcja Wydawnicza PTT w Krakowie, pod kierunkiem ks. prof. dra hab. Stanisława Grzybka, wydała kolejny, trzydziesty rocznik dwumiesięcznika Ruch Biblijny $i$ Liturgiczny, tom VIII Analecta Cracoviensia oraz dwa dzieła zbiorowe: Biblia na co dzień (drugie wydanie) i Teologia nauka o Bogu. Kongres Teologów Polskich Kraków 1976.

IV

W dniu 31 XII 1977 Polskie Towarzystwo Teologiczne w Krakowie liczyło 260 członków, w tym 225 zwyczajnych i 35 wspierających. W ostatnim roku zmarli członkowie zwyczajni Towarzystwa: ks. dr Ludwik Orzeł, profesor Śląskiego Wyższego Seminarium Duchownego oraz ks. mgr Władysław de Rosenburg Grohs, dziekan i proboszcz w Wieliczce. Krakớw

Ks. STANISEAW MEDALA

\author{
Wyd a w n i t w a \\ POLSKIEGO TOWARZYSTWA TEOLOGICZNEGO \\ w Krakowie \\ można zamawiać
}

REDAKCJA I ADMINISTRACJA RBL

ul. Augustiańska 7 .

31-064 KRAKÓW

telefon $621-80$ 